\title{
SUBTITUSI TEPUNG UBI JALAR \\ DALAM PEMBUATAN BOLU GULUNG
}

\section{SWEET POTATO FLOUR SUBSTITUTION OF ROLL CAKE}

\author{
Anton Ramadhan Ketra ${ }^{1}$, Okta Wulandra ${ }^{2}$ \\ 1) Program Studi Teknologi Pangan Fakultas Pertanian UNIVED \\ 2) Program Studi Teknologi Pertanian Fakultas Pertanian UNIVED
}

\begin{abstract}
ABSTRAK
Pembuatan bolu gulung dengan subtitusi tepung ubi jalar telah dilakukan. Penelitian ini bertujuan untuk menganalisis tingkat kesukaan panelis terhadap warna, rasa dan tekstur bolu gulung ubi jalar. Penelitian ini menggunakan variasi perlakuan formulasi tepung terigu dan tepung ubi jalar dengan tiga perlakuan yaitu perbandingan tepung ubi jalar : tepung terigu 750 gram : 250 gram ; 500 gram : 500 gram ; 250 gram : 750 gram. Parameter yang diamati adalah tingkat kesukaan panelis terhadap warna, rasa dan tekstur. Hasil penelitian menunjukkan bahwa bolu gulung tepung ubi jalar yang paling di sukai konsumen adalah dengan formulasi tepung ubi jalar 500 gram dan tepung terigu 500 gram.
\end{abstract}

Kata kunci : bolu gulung, tepung terigu, tepung ubi jalar

\section{ABSTRACT}

Making rolls cake with sweet potato flour substitution has been done. This study aimed to analyze the level of panelist preference for color, flavor and texture of sweet potato rolls cake. This study used a variation of the treatment formulations flour and sweet potato with three treatments, ie comparison of sweet potato flour : wheat flour 750 grams : 250 grams ; 500 grams : 500 grams ; 250 grams : 750 grams. Parameters measured were panelists preference level of the color, flavor and texture. The results showed that the sweet potato flour rolls in like most consumers is the formulation of sweet potato flour 500 grams and 500 grams of wheat flour.

Keywords : rolls cake, flour, sweet potato flour

\section{PENDAHULUAN}

Ubi jalar (Ipomoea batatas L) adalah jenis umbi-umbian yang memiliki banyak keunggulan dibanding umbi-umbi yang lain dan merupakan sumber karbohidrat keempat di Indonesia setelah beras, jagung, dan ubi kayu. Ubi jalar merupakan salah satu jenis makanan yang memiliki prospek cerah pada masa yang akan datang karena dapat dimanfaatkan sebagai bahan pangan penghasil karbohidrat juga sebagai bahan industri. Namun minat masyarakat untuk mengkonsumsi pangan asal ubi jalar masih rendah. Hal tersebut disebabkan pengolahan ubi jalar di Indonesia masih 
terbatas dan sederhana seperti direbus/dikukus, dipanggang, atau digoreng. Selain itu, timbul persepsi bahwa ubi jalar merupakan bahan pangan yang tidak sekelas dengan gandum atau jagung (Antarlina,S.S. dan Utomo.1991). Produk olahan ubi jalar dapat dihasilkan, baik sebagai bahan makanan, pakan ternak maupun bahan baku industri. Untuk lebih memanfaatkan ubi jalar dapat ditempuh dengan mengolahnya menjadi tepung dan bermanfaat sebagai bahan substitusi tepung terigu yang dapat diolah menjadi beberapa produk pangan. Tepung ubi jalar dibuat dengan langkah pembersihan dan pengupasan umbi, pensawutan ataupun pengirisan umbi, pengeringan, penepungan dan pengayakan hingga diperoleh produk dalam bentuk tepung halus (Hartoyo A, 1999).

Tepung ubi jalar memiliki kandungan karbohidrat yang tinggi sehingga baik digunakan untuk menghasilkan aneka produk pangan yang mempunyai nilai gizi, seperti bolu gulung. Bolu gulung merupakan produk olahan yang telah lama dikenal oleh masyarakat karena memiliki kandungan gizi yang cukup tinggi dan mudah dalam proses pengolahannya (Djuanda V, 2003). Bahan baku pembuatan bolu gulung adalah tepung terigu yang terbuat dari gandum, namun dapat disubtitusi dengan tepung ubi jalar. Bolu gulung dengan bahan baku tepung ubi jalar membutuhkan protein dalam bentuk gluten yang dimiliki tepung terigu. Kemampuan gluten pada tepung terigu menghasilkan tekstur bolu gulung menjadi empuk, meningkatkan cita rasa, sebagai sumber protein dan sumber karbohidrat (Desrosier, 2008).

\section{METODE PENELITIAN}

\section{Bahan dan Alat}

Bahan yang digunakan dalam melakukan penelitian iniadalah tepung terigu, tepung ubi jalar putih, susu, maezena, gula pasir, telor, kuning telor, pelembut, mentega cair, sedangkan alat-alat yang digunakan pada penelitian ini adalah timbangan, wadah, sendok, oven, mixer, loyang, pisau.

\section{Pembuatan Tepung Ubi Jalar}

Ubi jalar segar yang bebas dari hama dan penyakit. Ubi jalar dikupas kemudian diiris tipis atau disawut. Penyawutan dilakukan dengan alat penyawut /perajang yang digerakan secara manual atau tenaga motor. Sawut yang dihasilkan berupa irisan-irisan ubi jalar dengan lebar 0,2-0,4 cm, panjang $1-3 \mathrm{~cm}$, dan tebal $0,1-0,4 \mathrm{~cm}$. Sawut basah ditampung dalam bak pelastik atau wadah lain yang tidak korosif. Rendam hasil sawutan basah dengan larutan 
Sodium Bisulfit $(0,3 \%)$ selama 1 bila

Sodium bisulfit tidak tersedia dapat digantikan dengan larutan garam dapur. Untuk menghilangkan air dan larutan tersebut dilakukan pengepresan. Hasil pengepresan sawut tersebut harus diremahkan dengan memakai tangan secara pelan-pelan dan merata. keringkan (jemur) selama $10-16$ jam sampai mencapai kadar air 12 - 14\%, Sawut yang telah kering dapat disimpan atau langsung ditepungkan. Penggilingan sawut kering menjadi tepung ubi jalar dapat menggunakan mesin.

\section{Pembuatan Bolu Gulung}

Campurkan gula pasir $350 \mathrm{~g}$, telor ayam 11 butir, kuning telor 6 butir, pelembut 10 gram, kemudian di aduk selama kurang lebih 20 menit. Ketika pengadukan (mixing) sedang berjalan masukkan terigu 300g, maezena $100 \mathrm{~g}$, susu 100g, secara bertahap, kemudian 5 menit terakhir pengadukan masukan lagi mentega cair sebanyak 350g. Setelah pengadukan selesai, adonan kemudian dimasukkan ke dalam loyang berukuran $24 \times 24$ yang telah terlebih dahulu dilapisi dengan kertas minyak yang bertujuan supaya ketika selesai di oven adonan tidak lengket ke loyang sehingga mudah dilepas. Kemudian masukkan adonan ke dalam oven dengan suhu 170'c selama kurang lebih 50 menit. Setelah proses pengovenan selesai, adonan didinginkan terlebih dahulu selama lebih kurang 30 menit, Setelah proses pendinginan selesai, oleskan selai pada permukaan adonan, dan kemudian digulung (Murthado, T. 2002).

\section{HASIL DAN PEMBAHASAN \\ Warna Bolu Gulung}

Penentuan mutu suatu bahan pangan pada umumnya tergantung pada warna, karena warna tampil terlebih dahulu (Winarno, 2004). Warna produk pangan adalah salah satu sifat organoleptik yang terdapat pada produk pangan.Faktorfaktor yang mempengaruhi warna dari produk bolu gulung adalah penggunaan gula, telur dan tepung ubi jalar. Warna dapat memberikan penilaian yang berbeda terhadap pemakaian tepung ubi jalar yang baik. Daya tarik suatu jenis makanan lebih sering dipengaruhi oleh kenampakan warna sebagai salah satu sifat. Kenampakan mempunyai peran penting dalam menentuka mutu pangan.Selain sebagai faktor yang ikut menentukan mutu, warna juga dapat digunakan sebagai indikator kesegaran atau kematangan. Baik tidaknya cara pencampuran atau pengolahan dapat ditandai dengan adanya warna yang seragam dan merata (Anonim. 2008). 
Tabel 1. Tingkat Kesukaan Konsumen terhadap Parameter Warna Bolu Gulung Ubi Jalar

\begin{tabular}{ccc}
\hline No & Ubi Jalar : Tepung Terigu & Nilai Rata-rata \\
\hline 1 & 250 gram : 750 gram & 2,66 \\
2 & 500 gram : 500 gram & 2,50 \\
3 & 750 gram : 250 gram & 3,91
\end{tabular}

Keterangan skala penilaian :

$1=$ Suka sekali $: 2=$ Suka $: 3=$ Agak suka $: 4=$ Tidak suka $: 5=$ Sangat tidak suka

Tabel 2. Tingkat Kesukaan Konsumen terhadap Parameter Rasa

Bolu Gulung Ubi Jalar

\begin{tabular}{lcc}
\hline No & Ubi Jalar : Tepung Terigu & Nilai Rata-rata \\
\hline 1 & 250 gram : 750 gram & 2,66 \\
2 & 500 gram : 500 gram & 2,48 \\
3 & 750 gram : 250 gram & 3,94
\end{tabular}

Keterangan skala penilaian $1=$ Suka sekali $: 2=$ Suka $: 3=$ Agak suka $: 4=$ Tidak suka : 5 = Sangat tidak suka

Tabel 3. Tingkat Kesukaan Konsumen terhadap Parameter Tekstur

Bolu Gulung Ubi Jalar

\begin{tabular}{ccc}
\hline No & Ubi Jalar : Tepung Terigu & Nilai Rata-rata \\
\hline 1 & 250 gram : 750 gram & 2,73 \\
2 & 500 gram : 500 gram & 2,46 \\
3 & 750 gram : 250 gram & 3,87
\end{tabular}

Keterangan skala penilaian $1=$ Suka sekali $: 2=$ Suka $: 3=$ Agak suka $: 4=$ Tidak suka $: 5=$ Sangat tidak suka

Berdasarkan uji organoleptik mutu warna

(Tabel 1), bolu gulung tepung ubi jalar yang paling disukai oleh panelis adalah bolu gulung dengan subtitusi 500 gram tepung ubi jalar, karena panelis lebih menyukai warna agak ke kuningan kuningan. Sedangkan bolu gulung dengan subtitusi 250 gram ubi jalar memiliki warna yang pucat karena subtitusi ubi jalar terlalu sedikit, dan pada subtitusi tepung ubi jalar 750 gram memiliki warna gelap atau terlalu coklat karena subtitusi tepung ubi jalar terlalu banyak. Hal ini dipengaruhi oleh adanya reaksi pencoklatan akibat peristiwa karamelisasi dan terbentuknya ikatan antara gula dan protein. Jadi, semakn banyak tepung ubi jalar maka hasil 
olahan menjadi bolu gulung akan semakin coklat

\section{Rasa Bolu Gulung}

Rasa adalah faktor yang mempengaruhi penerimaan produk pangan. Jika komponen warna dan tekstur baik tetapi konsumen tidak menyukai rasanya maka konsumen tidak akan menerima produk pangan tersebut (Rampengan dkk., 1985). Rasa biasanya ditentukan oleh salah satu zat dominan dan bersifat professional dalam susunan zat-zat yang memberikan rasa. Cita rasa juga sangat mempengaruhi derajat penerimaan konsumen (Anonim, 2009).

Berdasarkan uji organoleptik mutu rasa (Tabel 2), bolu gulung tepung ubi jalar yang paling disukai oleh panelis adalah bolu gulung dengan subtitusi 500 gram tepung ubi jalar, karena memiliki rasa yang enak dan manis, Sedangkan bolu gulung dengan subtitusi 250 gram tepung ubi jalar memiliki rasa yang kurang manis, karena subtitusi tepung ubi jalar nya terlalu sedikit, sementara bolu gulung dengan subtitusi 750 gram tepung ubi jalar memiliki rasa yang terlalu manis karena subtitusi tepung ubi jalarnya terlalu berlebihan.Hal dipengaruhi oleh beberapa jenis gula yang bersifat larut seperti maltosa, sukrosa, fruktosadan glukosa yang terkandung pada ubi jalar.

\section{Tekstur Bolu Gulung}

Tekstur memiliki pengaruh penting terhadap produk bolu gulung misalnya dari tingkat kelembutan, keempukan, dan kekerasan,dan sebagainya. Tekstur merupakan sensasi tekanan yang dapat diamati dengan mulut (pada waktu digigit, dikunyah, dan ditelan) ataupun perabaan dengan jari (Kartika, dkk., 1988). Tekstur produk pangan merupakan salah satu komponen yang dinilai dalam uji organoleptik bolu gulung tepung ubi jalar.

Berdasarkan uji organoleptik mutu tekstur (Tabel 3) penelis/konsumen menyukai bolu gulung dengan subtitusi 500 gram tepung ubi jalar, karena dilihat dari tekstur dari ketiga sampel, bolu gulung tepung ubi jalar dengan subtitusi 500 gram lebih halus sehingga setelah di oven bolu lebih padat dan kenyal, sedangkan bolu gulung dari sampel yang bersubtitusi 250 gram tepung ubi jalar memiliki permukaan yang keras sedangkan bolu gulung dengan subtitusi 750 gram tepung ubi jalar mempunyai tekstur yang permukaanya pecah-pecah dan tidak kalis. Hal ini dipengaruhi oleh gluten yang terkandung dalam protein tepung fungsinya sebagai pembentuk tekstur yang membuat kue mengembang besar dan empuk. 


\section{SIMPULAN}

Berdasarkan parameter warna, panelis konsumen lebih menyukai bolu gulung dengan subtitusi 500 gram tepung ubi jalar dengan nilai rata-rata 2,50 yang berada pada skala suka. Berdasarkan atribut mutu rasa, panelis konsumen lebih menyukai bolugulung dengan subtitusi 500 gram tepung ubi jalar dengan nilai rata-rata 2,48 yang berada pada skala suka. Berdasarkan atribut mutu tekstur, panelis konsumen lebih menyukai bolu gulung dengan subtitusi 500 gram tepung ubi jalar dengan nilai rata-rata 2,46 yang berada pada skala suka. Produk bolu gulung dari tepung ubi jalar yang paling baik berdasarkan uji organoleptik yaitu pada subtitusi tepung ubi jalar 500 gram dan dengan 500 gram tepung terigu

\section{UCAPAN TERIMA KASIH}

Penulis menyampaikan rasa penghargaan dan terima kasih kepada yang terhormat Kedua orang tua yang tidak pernah bosan mencurahkan kasih dan sayang, dukungan serta do'a :Ibu Epina Felizita Bando,S.KM,M.Kes, selaku pemilik perusahaan Roti Vanda Bakery sebagai tempat pelaksanaan penelitian.

\section{DAFTAR PUSTAKA}

Anonim, 2008 . Budi daya/ Pembuatan tepung ubi jalar. Diakses tanggal 28 Juni 2013.

Antarlina,S.S. dan Utomo. 1991. Pengaruh Umur Panen dan Klon terhadap Beberapa Sifat Sensoris, Fisik dan Kimiawi Tepung Ubi Jalar. Tesis. Program Pasca Sarjana Universitas Gajah Mada. Yogyakarta.

Desrosier, 2008. Teknologi Pengawetan Pangan. Penerjemah $M$. Muldjohardjo. UI - Press, Jakarta.

Djuanda, V. 2003. Optimasi Fomulasi Cookies Ubi Jalar (Ipomea batatas) Berdasarkan Kajian Preferensi Konsumen. Skripsi Fakultas Teknologi Pertanian, IPB Bogor.

Hartoyo, A, 1999. Kajian Teknologi Pembuatan Tepung Ubi Jalar Instant Kaya Pro Vitamin A. Skripsi Fakultas Teknologi Pertanian, IPB, Bogor.

Irfansyah. 2001. Karakteristik FisikoKimia dan Fungsional Tepung Ubi Jalar (Ipomoea batatas L) serta Pemanfaatannya untuk Pembuatan Kerupuk. Tesis. Program Pascasarjana, IPB, Bogor.

Kartika B, dkk. 1988. Pedoman Uji Inderawi. PAU Pangan dan Gizi Universitas Gadjah Mada. Yogyakarta.

Murthado, T. 2002. Bolu gulung. Gramedia pustaka utama, Jakarta.

Rampengan, V.J. Pontoh dan D.T. Sembel., 1985. Dasar-dasar Pengawasan Mutu Pangan. Badan Kerja Sama Perguruan Tinggi Negeri Indonesia Bagian Timur, Ujung Pandang. 